\title{
Exchanges
}

In the Exchanges, we present conversations with scholars and practitioners of community engagement, responses to previously published material, and other reflections on various aspects of community-engaged scholarship meant to provoke further dialogue and discussion. We invite our readers to offer in this section their own thoughts and ideas on the meanings and understandings of engaged scholarship, as practiced in local or faraway communities, diverse cultural settings, and various disciplinary contexts. We especially welcome community-based scholars' views and opinions on their collaboration with university-based partners in particular and on engaged scholarship in general.

Below, Christopher Hrynkow talks to Maria C. Power about her community-based research and her vision for engaged scholarship as undertaken by religious historians. Dr. Maria Power, PhD (History, Royal Holloway), is a lecturer in Religion and Peace Building at the Institute of Irish Studies, University of Liverpool. Her research focuses on the relationship of faith to politics, especially in areas of conflict, and the role that religious organisations play in peacebuilding.

\section{Conversation with Maria Power, University of Liverpool}

Christopher Hrynkow: Can you please share a bit about your research and how it engages issues at the intersection of faith and community?

Maria Power: My research takes a grassroots approach to the issue of faith, most particularly Christianity, and the way in which ordinary people understand and perform their faith in the public square. Having grown up in the Irish community in London during the 1980s, I have a particular interest in the conflict in Northern Ireland so it seemed natural to start my research career by exploring the role that ordinary Christians

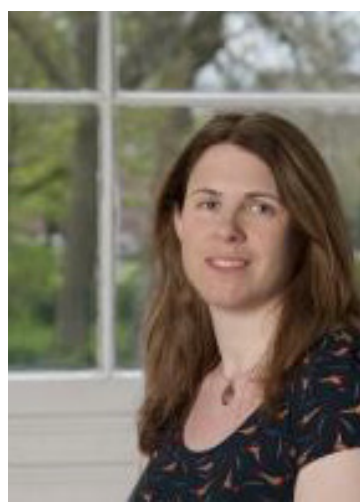
played in the peace process there. I found that ecumenical faith-based groups placed themselves at the service of the communities most ravaged by violence, and made a difference by promoting a vision of gospel values that stressed unity over division. Since completing that work I have started a research project looking at the role that Catholic peace activists played in the anti-Apartheid movement in Britain during the 1980s, and have found that they brought a profound reading of the teachings of the gospel into the secular groups that they worked with. 
Christopher: OK, let us start with your work on Northern Ireland. Before we discuss your intriguing findings, can you share a bit about your research design? What time period did you consider and why? How did you access and analyse the stories and projects of 'ordinary' Christians trying to build peace in Northern Ireland?

Maria: I decided to look at the period between 1980 and 2005 for two reasons: the first was quite prosaic, as someone had already written a book on inter-church relations in Northern Ireland from 1968-1980, and the purpose of a PhD is to produce something new. The second was quite personal: my earliest political memories, which are from the early 1980s, are dominated by fear and the need to remain silent in case you upset someone. For instance, we were in Northern Ireland in 1981 when the hunger striker Bobby Sands passed away I was 4 at the time and I remember (1) being very confused by the hushed conversations amongst the adults and (2) the concern every time someone knocked on the door. So I think that I chose this topic on some level because I wanted to see if there was a counter-narrative to this, if the conflict and its causes were discussed, and if, in any way, the two communities mixed with one another.

Access was actually much more simple than one would think. The Community Relations Council had produced a directory of all these inter-church groups so I started there. I wrote to each group, introducing myself and asking if I could come and talk to them. They were wary at first but once I had gained their trust, through a mixture of the fact that my parents are Irish; that I was genuinely interested in living out gospel values myself; and was happy to pray and worship with them, they were willing to introduce me to others working in this area. By the time I'd finished this project, I'd interviewed around 70 people.

Christopher: Did this approach cause any controversy in the History department at Royal Holloway where you were studying or did community engaged research already have a foothold there? What were some of the main things you learned and experiences you had during the community-based interviews themselves?

Maria: Royal Holloway was founded in the $19^{\text {th }}$ Century as a women's college, and was therefore progressive in its attitudes from the outset. As a 17 year old, I had deliberately chosen to read [study, in North American terms] history there as a consequence of its feminist credentials and the fact that the history department contained a number of historians who were at the cutting edge of their fields. Women's history was naturally a very strong component within the department and even in the 1990s, as a discipline it was viewed as somewhat avant garde as it involved unearthing the hidden histories of women. Although my attention pivoted towards religion and conflict during my MA, my methodological approach, which involved an in depth engagement with the communities I was researching and telling their stories from their perspective, was a natural progression from the example that had been set for me by the likes of the historians Lyndal Roper, Penny Corfield, and 
of course my supervisor, John Turner.

I learnt a good deal during my time working in the field in Northern Ireland. First, when to stop asking questions! There are some things that people just won't talk about even still and pushing them on these issues can be damaging both for the participant and the researcher. I find it hard now when I see younger researchers trying to 'dig up stories' that people aren't ready to talk about. All history has a time, and some of it needs to be left to percolate in the participants' consciousness longer than others. Second, you bring a lot of yourself to the research process when working with communities. When starting, I had quite naively believed that something called 'impartiality' actually existed. It doesn't and one of the signs of a good researcher is that they can mitigate against this when researching and writing up their findings.

Christopher: Thank you, that is really interesting. Can you now say a bit more about your findings and how this community engaged approach served to bring into focus the role of ordinary people in peacebuidling? What, in particular, did you find that indicated that these peacebuilders' faith was a motivation for their community-based work in Northern Ireland?

Maria: Until recently most of the research being carried out in Northern Ireland was focused on the elites, such as politicians. Working in the area of religion, it would be very easy to fall into this trap and just focus on the church leadership. I did interview church leaders, but what I gained from those interviews was an understanding of how the church operated and how much pride these men (they were all men I'm afraid) took in the activities of their congregations. As far as they were concerned, the leadership was just there to facilitate the work within the community and to offer it moral support. This confirmed my own experiences with faith-based organisations, that the most interesting things are happening away from the churches themselves and that the only way to uncover the depth of activity was to go out into the communities and engage with the parishioners. The main, and most interesting, finding from my research was the wealth of engagement across sectarian lines that was taking place within communities. Whilst this work may not have looked that significant from the outside, it was incredibly meaningful in helping to ensure that loving relationships were being built at a time when the prevailing ethos was one of hate and suspicion. The one thing that struck me was that all of my interviewees stated clearly to me that they were motivated by their faith, and many had a particular text from the New Testament that guided their engagement.

Christopher: And just so our readers can see some of the potential here, can you name some of those verses and explain a bit about how they resonated with your research participants?

Maria: Most of the verses that were used are the ones that we'll all be familiar with. So for example, 'blessed are the peacemakers' which provided the primary motivation for 
the participants, especially in their initial engagements with one another. One group in particular were very motivated by the Acts of the Apostles and saw their community as a modern manifestation of the early church. In many ways this group did have a very energetic and novel feel to it, and, whilst they didn't proselytise, they did evangelise by their love for those that they worked with.

Christopher: A very compelling project addressing community-based peacebuilding in Northern Ireland! How did your work on that project tie in with your choice to look at anti-Apartheid activists in Britain during the 1980s?

Maria: Again, I bring something of myself to this project. I remember being very inspired by the campaign in the UK to end apartheid, and although I was far too young to go to the protests myself, I wanted to go! As I've become more involved in peace activism in London and started to talk to others about their histories in the movement, I've realised that many were very involved in the anti-apartheid movement in the 1980s, and see it as a formative experience. This, when combined with the fact that some of the most prophetic theology of the $20^{\text {th }}$ century was created as a result of this struggle in South Africa itself, made it seem very obvious to me that there was an interplay between faith and activism in the UK as well. So, this project will either prove or disprove this hypothesis.

Christopher: What elements of community engaged methodology are you employing with this project on UK-based anti-apartheid activism?

Maria: Again, I'm taking a very grassroots approach to the project, and this time I'll be interviewing people with whom I've engaged in peace activism with. I'm also planning some participatory workshops using artefacts, such as posters and t-shirts, from the era as a way of getting people talking about their engagement with the movement. I'm very much looking forward to these as I've never done anything like this before so it will bring fresh methodological challenges, such as working with larger groups and with people who might not necessarily have linked their faith to their activism.

Christopher: Thank you very much for your time. To end and to give you the last word, I am wondering if you might offer some general thoughts and reflections on the role for community engaged research in the study of religious history.

Maria: I think that if we're ever going to understand the development of faith-based communities and groups in any context, we have to engage with the communities themselves. This is where theologians, especially bishop and priest theologians, gain their insights, ideas and inspiration. Furthermore, there is so much wisdom to be gained from grassroots and community activists, these are the people at the coalface of an area's issues and experience leads them to develop innovative ways to solve the problems that they deal 
with constantly. Given the times we're living in, ideas and solutions need to be circulated as widely as possible.

\section{About the Contributors}

Christopher Hrynkow earned a PhD in Peace and Conflict Studies from the Mauro Centre for Peace and Justice, St. Paul's College, University of Manitoba and a ThD in Christian Ethics, specializing in Ecological Ethics, awarded jointly by the University of Toronto, the University of St. Michael's College, and the Toronto School of Theology. He is currently an Associate Professor in the Department of Religion and Culture at St. Thomas More College, University of Saskatchewan where he teaches courses in Religious Studies, Catholic Studies, and Critical Perspectives on Social Justice and the Common Good. Email: chrynkow@stmcollege.ca

Maria C. Power's first monograph focused upon faith-based organisations and their contribution to the peace process in Northern Ireland. She has recently published an edited collection entitled Building Peace in Northern Ireland, which provides the first historical overview of the contribution of peace movements in the region. It demonstrated that more focus needs to be given to peace and reconciliation within communities and that the peace process in Northern Ireland is an ongoing project with issues such as deprivation needing urgent attention if it is to continue to be successful. Dr Power is currently finishing a monograph exploring the role of the Catholic Church in the conflict in Northern Ireland entitled Seeking the Peaceable Kingdom: Cardinal Cahal Daly, Nonviolence and the Quest for Justice in Northern Ireland, Her next project will be a co-authored study of the Papacy and Nonviolence. As well as her academic work, she has also written for publications such as the Irish Times, and The Conversation on issues related to Catholicism and social justice. Dr Power is a trustee of Good Works, an organisation dedicated to promoting ethics in the work place, and she is one of the founders and Principal Investigator of the Beliefs, Values, and Worldviews at Work: a ground-breaking research programme exploring the role of faith in the work and business environment. Home page: https://www.liverpool.ac.uk/irish-studies/staff/maria-power/ 